
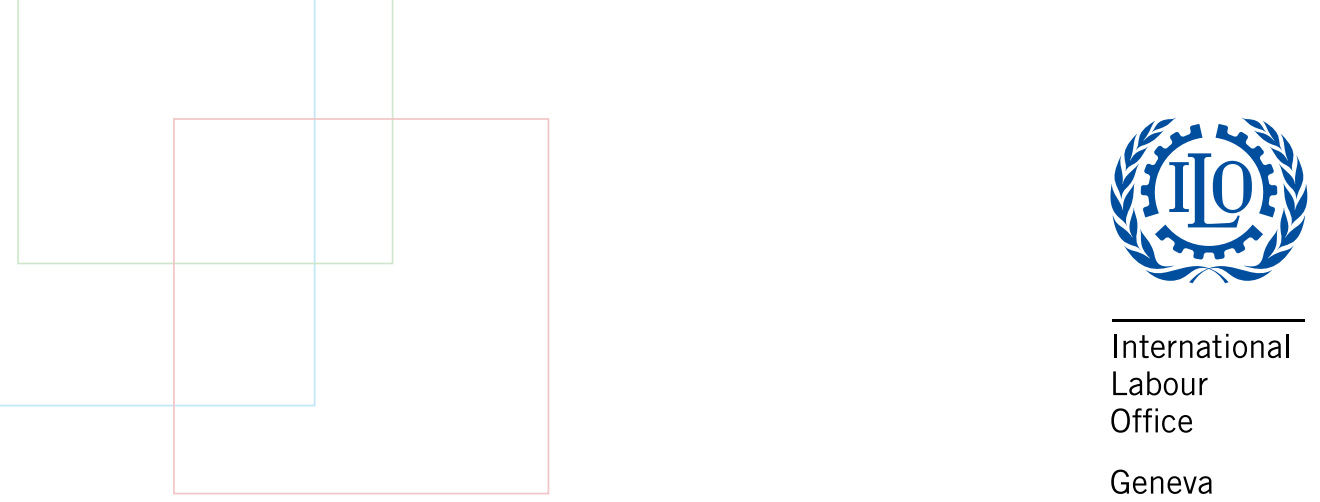

$\overline{\text { International }}$ Labour

Office

Geneva

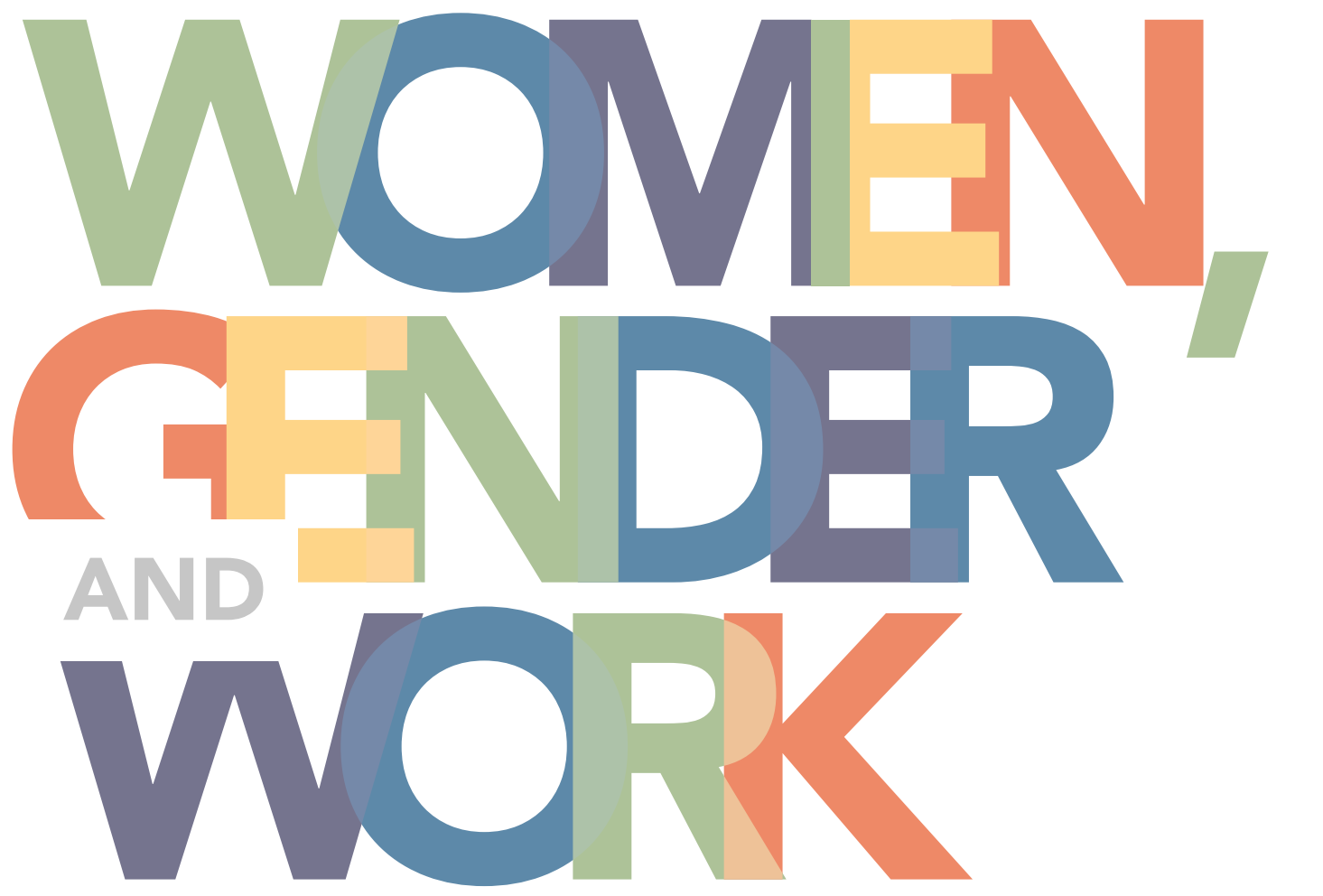

Volume 2

SOCIAL CHOICES AND INEQUALITIES 


\section{WOMEN, GENDER AND WORK}




\title{
WOMEN, GENDER AND WORK
}

\section{Volume 2}

\section{Social choices and inequalities}

Edited by

Mark Lansky, Jayati Ghosh, Dominique Méda and Uma Rani

\author{
Prefaced by \\ Martha C. Nussbaum
}

INTERNATIONAL LABOUR OFFICE - GENEVA 
Copyright (C) International Labour Organization 2017

First published 2017

Individual chapters (C) The authors

Each chapter in this volume has been - or will shortly be - published in the ILO's International Labour Review. The International Labour Review is published on behalf of the International Labour Organization by Wiley-Blackwell, United Kingdom.

Publications of the International Labour Office enjoy copyright under Protocol 2 of the Universal Copyright Convention. Nevertheless, short excerpts from them may be reproduced without authorization, on condition that the source is indicated. For rights of reproduction or translation, application should be made to ILO Publications (Rights and Licensing), International Labour Office, CH-1211 Geneva 22, Switzerland, or by email: rights@ilo.org. The International Labour Office welcomes such applications.

Libraries, institutions and other users registered with a reproduction rights organization may make copies in accordance with the licences issued to them for this purpose. Visit www.ifrro.org to find the reproduction rights organization in your country.

Lansky, Mark; Ghosh, Jayati; Méda, Dominique; Rani, Uma

Women, gender and work (Vol. 2): Social choices and inequalities / Lansky, Mark; Ghosh, Jayati; Méda, Dominique; Rani, Uma (editors); International Labour Office. - Geneva: ILO, 2017

ISBN: 978-92-2-130869-0 (print)

ISBN: 978-92-2-131165-2 (web pdf)

International Labour Office

gender equality / economic and social development / sexual division of labour

04.02 .3

ILO Cataloguing in Publication Data

The designations employed in ILO publications, which are in conformity with United Nations practice, and the presentation of material therein do not imply the expression of any opinion whatsoever on the part of the International Labour Office concerning the legal status of any country, area or territory or of its authorities, or concerning the delimitation of its frontiers.

The responsibility for opinions expressed in signed articles, studies and other contributions rests solely with their authors, and publication does not constitute an endorsement by the International Labour Office of the opinions expressed in them.

Reference to names of firms and commercial products and processes does not imply their endorsement by the International Labour Office, and any failure to mention a particular firm, commercial product or process is not a sign of disapproval.

ILO publications and digital products can be obtained through major booksellers and digital distribution platforms, or ordered directly from ilo@turpin-distribution.com. For more information, visit our website: www.ilo.org/publns or contact ilopubs@ilo.org.

Information on the International Labour Review, including subscriptions, can be obtained from Wiley-Blackwell at http://onlinelibrary.wiley.com/journal/10.1111/(ISSN)1564-913X. 


\section{Acknowledgements}

Special thanks are due to the authors of the 32 articles presented in this volume for contributing their work to the International Labour Review and, to those of them whose work was originally published in the 2000s, for sending us updates to assist us in drafting the introduction. We are equally grateful to our editorial advisers and others who kindly helped in reviewing the original submissions over the years, including David Kucera, Deborah Levison, Martha F. Loutfi, Martha Nussbaum, Paul Osterman, Shahra Razavi, Christine L. Smith, Manuela Tomei and Raymond Torres. We also wish to thank the latter for supporting this project in his capacity as Chairman of the journal's Editorial Board and Director of the ILO Research Department.

The material in this volume was checked, carefully edited and revised by the staff of the ILR - namely, Deborah Adams, Patrick Bollé, Gaëlle Bossi, Luis Lázaro Martínez, Lola Montero Cué, Marie-Christine Nallet, Kate Pfeiffenberger and Christine L. Smith. It was finally turned into publishable form by staff at the ILO's Document and Publications Production, Printing and Distribution Branch. 


\section{Preface}

Most of the world's adult women work many hours a day. Their work is sometimes paid, sometimes unpaid; sometimes meaningful, sometimes monotonous; sometimes chosen, sometimes a necessity. Sometimes women work in conditions that protect their health, safety, and bodily integrity; sometimes they encounter health hazards, crushing hours, and sexual harassment or even violence. To sum it all up, sometimes women's work shows respect for their equal human worth, and sometimes it does not.

This impressive volume continues the study of women and work begun in Volume 1. This volume deliberately focuses on practical strategies and less on theory, but in the process it sheds light on a number of highly practical theoretical issues.

First, what is work? Most definitions of work in economics contrast wage labour with unpaid household labour, and some even classify the latter as a leisure activity. Obviously that is inadequate. Much of the work women do around the world is unpaid care and domestic labour, and even when women also have a job outside the home they typically shoulder a large proportion of child care, elder care, and homemaking. The present volume, by contrast, begins with the conceptually revolutionary definition of the 19th International Conference of Labour Statisticians: "Work comprises any activity performed by persons of any sex and age to produce goods or to provide services for use by others or for own use" (Introduction, p. 22). Many essays in the volume then reflect productively on how we might assign a hypothetical monetary value to women's household labour, and also how we may enhance the dignity and working conditions of those who provide such services for a wage, given that these services are currently devalued on account of their gendered history.

Another crucial theoretical question that pervades these excellent, diverse, and rigorous essays is that of the value of work and its relation to the good life. As the Introduction notes, work has not always been understood as a constituent part of the good life. For much of history, at least in the Western tradition and in the Indian tradition (the only non-Western tradition at all known to me), work has been thought of as instrumental to things that are really important, rather than as having any inherent value. Thus in ancient Greece (at least for the elites who dominate philosophical discourse) the free citizen was imagined as someone who had a lot of free time, and did not have to make money. Indeed women were often assigned the job of estate management precisely because that task was thought to be banal, base, and lacking in inherent value. The Indian tradition imagined the life of the "householder" as 
a phase to be transcended in the direction of a solitary religious life (usually for males, who were free to make this choice).

Such ideas persisted for millennia, as elites disparaged people who did wage labour and disparaged, at least as much, women's unpaid domestic labour. But by the nineteenth century, a different view became common: that work is an important aspect of human self-definition, and that its configuration thus has immense importance for the fate of human dignity in class-stratified social worlds. Marx held that workers are alienated from their own humanity because they are permitted neither to control the product of their labour nor to organize and affiliate with other workers. This view, enormously influential thenceforth, has led to a set of questions that urgently demand answers. What are the conditions under which work is meaningful? What types of control must workers have over their work in order to be dignified people rather than serfs? What protections for health, safety, bodily integrity, and leisure must be part of a decent labour arrangement?

These questions obviously pertain to women's work, but they have rarely been posed clearly about the "informal economy", in which a large proportion of the world's women are employed, and still more rarely about women's unpaid care and domestic work, whether combined with wage labour or not. The essays in this volume thus break new ground and help us all to press such questions further.

We need to think, as well, about what work precludes: that is, about leisure and play. Human beings need time to reflect, to imagine, to develop friendships, community affiliations, and political concerns. Many of these "leisure" pursuits are made impossible for women by the "double day" - the extra burden of domestic labour at the close of a taxing day of work outside the home.

The essays assembled here suggest directions for law in shaping women's opportunities, but they also make it clear that social attitudes and changes in the shape of the workplace are also part of any meaningful solution.

The world economy is changing, and these changes have implications for women's work. Specifically, the transition to a service economy has made education far more central for employment than in previous generations. When women get educational opportunities, they excel: women are overrepresented in most of the world's universities. But ongoing problems with primary education need to be solved if the world's women are to realize their potential. This volume also sheds new light on these urgent current issues.

In my contribution to Volume 1 of Women, gender and work, I defended (my version of) the Capabilities Approach as a helpful way of looking at goals for women and work. The present volume convinces me that these arguments are still important. The Capabilities Approach is valuable in this area, first of all, because we need to consider work in a larger context of what women are able to do and to be, a context that includes life, health, bodily integrity, practical reason, emotional health, affiliation, play, and the other capabilities on my list. The list helps us remember what to look for. By focusing on substantive opportunities, it also provides a rationale for affirmative efforts: if women are 
to reach the same level of capability as men, social institutions must in most cases work harder to overcome existing injustice. The approach thus offers a useful corrective to merely formal approaches to equality and non-discrimination. The focus on capability - rather than actual functioning - makes room for choice and expresses respect for women's agency.

Although my version of the Capabilities Approach focuses on law and political principles, it can also be used to study workplace policies and family attitudes, so it is a flexible tool that can assist us as we diagnose problems and recommend solutions.

This splendid and challenging volume, a feast of diverse arguments and perspectives, makes me hungry for even more. So what do I propose for a future Volume 3? I would like to see more about progress in law on issues of sexual harassment and sexual violence. I would like to see more about the contrast between work and leisure or play, and about the value of each in a meaningful life. As we approach a future in which much work will be done by automata, we need to think about how governments can extend to people meaningful active lives without many of the types of work they used to do. What will take that place? What new forms of work, and of meaningful activity outside work, should we encourage?

But a major focus of any future volume must be on the relationship between gender and ageing. All populations are ageing, and ageing raises many new issues of justice that bear on women's role. First and obviously, there is now - as there will be as time goes on - more and more care labour to be done; and caring for ageing relatives is usually more difficult, physically and emotionally, than caring for children. At present most countries leave such care to the family, and it is therefore primarily assigned to women, as if they will do it without pay for love. We must think better about how to provide this care on an equitable basis while respecting the dignity of ageing people and without debarring younger women from other work and chosen activities.

Second, women make up a large proportion of the world's ageing people. So issues of justice and inclusion that arise in this sphere pertain especially to women. The evil practice of compulsory retirement, still practised in most countries, removes active women from the work that they love, marginalizing them and diminishing their self-respect. I am sixty-nine, and I am lucky to be able to work as long as I wish and am able; my friends in other countries are not so lucky. A variety of arguments are marshalled to defend this practice, but they all fail. Justice usually costs more than injustice, but we have never thought that the extra cost of including people with disabilities in schools and workplaces counted against their inclusion: indeed courts have ordered schools to integrate such children as an instance of the equal protection of the laws, and employers in the United States are required by law to make "reasonable" accommodations to equip the workplace for any special physical issues that an employee may have, a conclusion with obvious implications for ageing workers.

The age when one must stop working is and should be different from the age at which one may stop working; and there should be clarity on this point, 
as well as encouragement for career transitions for people in their sixties and seventies who may want to change paths, and public support for late-life education, a time when most of us search for meaning.

Age discrimination, now ubiquitous in all countries, must stop. Now people look the other way, as if it were "just nature", and therefore not at all the same bad thing as racial or gender discrimination. Of course, it is. As John Stuart Mill remarked about the subordination of women, so here: "Was there ever any domination which did not seem natural to those who possessed it?"

Isolation and lack of mobility are big capability issues for ageing people, and women are especially likely to live alone, isolated from friends and community. So a focus on issues of mobility without relying on the car, whether through access to public transportation or through a future of self-driving cars, is a major aspect of getting ageing women to work or to play, as they choose.

The stigma currently attached to the ageing body is just as damaging as racial stigma or the stigma against people with disabilities, and it falls most heavily on ageing women, since ageing male bodies code as powerful and seductive, while a long tradition sees ageing female bodies as useless. Stigma is an issue for law indirectly: there is much that institutions can do to change social attitudes to women's bodies, by public rhetoric and also by inclusion in the workplace.

Law is in its infancy in this area. We need new work on competency and guardianship (different, often, in different areas of life), and on the conditions under which ageing people can express consent to sex and/or marriage and divorce. Once again, all these issues are disproportionately significant for women, since women are disproportionately represented among the ageing.

In short: this volume is a huge contribution, and it is to be warmly applauded. Now let us get to work on the next step. 


\section{Contents}

Acknowledgements $\quad \mathrm{v}$

Preface

by Martha C. NUSSBAUM vii

\section{PART I - Introduction}

1. Social choices and inequalities

by Mark LANSKY, Jayati GHOSH, Dominique MÉDA and Uma RANI

\section{PART II - Concepts and conceptions}

2. Equality and empowerment for decent work

3. Discrimination and equality at work: A review of the concepts

by Manuela TOMEI

4. Inequality at work in the informal economy: Key issues and illustrations

5. Distribution of income and job opportunities: Normative judgements from four continents

by Deborah LEVISON, Joseph A. RITTER, Rosamund STOCK and Richard ANKER

6. Missing women? The under-recording and under-reporting of women's work in Malaysia

by Anja Karlsson FRANCK and Jerry OLSSON

7. Life domain preferences among women and men in Israel:

The effects of demographic variables

by Moshe SHARABI

\section{PART III - Female labour force participation: Gender gaps and segregation}

8. Globalization, social exclusion and gender

by Marilyn CARR and Martha CHEN

9. Closing the gender gap in education: What is the state of gaps in labour force participation for women, wives and mothers 
Women, gender and work

10. Ethnic wage gaps in Peru: What drives the particular disadvantage of indigenous women?

by Alexandre KOLEV and Pablo SUÁREZ ROBLES

11. Unlimited unskilled labour and the sex segregation

of occupations in Jamaica

by Heather E. RICKETTS and David V. BERNARD

12. Falling female labour force participation in Kerala: Empirical evidence of discouragement?

by Shalina Susan MATHEW

13. Gender equality at work in sub-Saharan Africa: A case study of Mali's modern sector

by Saliha DOUMBIA and Dominique MEURS

14. The socio-cultural dimension of women's labour force participation choices in Switzerland

by Fabio B. LOSA and Pau ORIGONI

15. Gender equality, part-time work and segregation in Europe

by Theo SPARREBOOM

16. Gender and labour in times of austerity: Ireland, Italy and Portugal in comparative perspective

by Tindara ADDABBO, Amélia BASTOS, Sara Falcão CASACA, Nata DUVVURY and Áine NÍ LÉIME

\section{PART IV - From unpaid to underpaid:} The care-work continuum

17. Care workers in Argentina: At the crossroads of labour market institutions and care services by Valeria ESQUIVEL 385

18. Underpaid and overworked: A cross-national perspective on care workers by Shahra RAZAVI and Silke STAAB 403

19. How care-work employment shapes earnings in cross-national perspective by Michelle J. BUDIG and Joya MISRA

20. Discounted labour? Disaggregating care work in comparative perspective by Naomi LIGHTMAN 439

21. Hierarchies of care work in South Africa: Nurses, social workers and home-based care workers

by Francie LUND

22. The expansion of social care and reform: Implications for care workers in the Republic of Korea

by lto PENG

23. Care arrangements and bargains: Anganwadi and paid domestic workers in India

by Rajni PALRIWALA and N. NEETHA

24. Childcare and geographical mobility in southern Europe

by Ildefonso MÉNDEZ 515

25. The globalization of nurse migration: Policy issues and responses 


\section{PART V - Regulation of "women's work": A mixed record}

26. Night work of women in industry: Standards and sensibility by George POLITAKIS 559

27. Women in the Japanese labour market, 1947-2003: A brief survey by Junko KUMAMOTO-HEALEY 583

28. Social security reform and gender equality: Recent experience in central Europe

by Elaine FULTZ and Silke STEINHILBER 603

29. The ILO's Domestic Workers Convention and Recommendation: A window of opportunity for social justice by Martin OELZ

\section{PART VI - Organization for empowerment and better work}

30. Collective bargaining and equality: Making connections

$$
\text { by Adelle BLACKETT and Colleen SHEPPARD }
$$

31. Challenges facing nurses' associations and unions:

A global perspective

by Paul F. CLARK and Darlene A. CLARK 693

32. Organizing migrant care workers in Israel: Industrial citizenship and the trade union option

by Guy MUNDLAK and Hila SHAMIR

33. Can more inclusive wage-setting institutions improve low-wage work? Pay trends in the United Kingdom's public-sector hospitals

by Damian GRIMSHAW 735 


\title{
Care workers in Argentina: At the crossroads of labour market institutions and care services
}

\author{
Valeria ESQUIVEL*
}

\begin{abstract}
In Argentina, one-third of all employed women, but only 3 per cent of all employed men, are care workers. Their relative pay and working conditions depend not only on applicable labour market regulations (and enforcement) but also, crucially, on the organization of care service provision, including the degree of public-sector engagement in the provision of particular services, the different care providers, and the locus of care provision (institutional vs other contexts, e.g. households). Comparing two childcare-related occupations (early-education teaching and domestic service), the author argues that those two - possibly mutually reinforcing - dimensions intersect to explain differences between care workers' labour market positions.
\end{abstract}

$\mathrm{n}$ the past 15 years, the feminist economics literature has seen the emergence of a new concept, the "care economy", as a result of the shift "from labour to care" (Himmelweit, 2000). The old emphasis on women's and households' unpaid care work ${ }^{1}$ gave way to a new framework, defined "more specifically, focusing on the labor process rather than the relationship to the site of production (home versus market) or the production boundary (in the SNA or not)" (Folbre, 2006a, p. 186). ${ }^{2}$ In the process, the care-economy framework has expanded the analysis of unpaid care work by including also the study of care work performed in the paid economy - the work of care workers.

Following England, Budig and Folbre, this article defines care workers as wage workers whose occupations involve providing a "face-to-face service that develops the human capabilities of the recipient" (2002, p. 455). This typically

Originally published in International Labour Review, Vol. 149 (2010), No. 4.

* Universidad Nacional de General Sarmiento, Buenos Aires, email: vesquive@ungs.edu. ar. The author wishes to thank Rosalía Cortés, Marcela Cerrutti, Shahra Razavi, Silke Staab and two anonymous reviewers, for their comments and suggestions on a previous version of this article.

${ }^{1}$ Unpaid care work corresponds with "extendedSNA" (System of National Accounts) activities, i.e. care of persons, housework, and voluntary work.

${ }^{2}$ In much of the "Northern" literature at least, that emphasis implied a narrower focus on the "direct" care-of-persons component of unpaid care work, excluding most instrumental housework tasks, like cleaning or cooking. For an alternative approach in a development context, see Razavi (2007). 
includes the work of doctors and nurses, early-education, primary and secondary school teachers and aides, university-level professors, therapists and nannies. It also includes domestic workers, whose work content is more loosely defined but cannot be excluded from the analysis of care occupations in Argentina. Domestic workers are expected to cook, clean and do the ironing, but they also mind children and take care of elderly or infirm household members if required - the work content of their jobs accommodates the needs of the employer's household.

The sex-typing of unpaid care work - which, at least in Buenos Aires, is still overwhelmingly women's work (Esquivel, 2010) - extends to domestic workers, who are almost invariably women. The association of unpaid care work with "natural" female characteristics - and not with skills acquired through formal education or training - also implies that most domestic workers have low formal educational credentials. Conceptually, the inclusion of domestic workers in the analysis of care work is based on the idea that care - particularly that performed within households - encompasses both direct care of persons and indirect care, in the form of housework that is a prerequisite for the former to be performed on an unpaid basis (Folbre, 2006a, p. 188; Razavi, 2007, p. 6).

Previous research on paid care work has found that care workers are, in some contexts, relatively low paid and their working conditions deficient as compared to other groups of workers. ${ }^{3}$ Some explanations for this have focused on the work content of care occupations, associated with women and mothering and therefore socially undervalued, which might affect "people's sense of how much the [care] job should be paid" (England, Budig and Folbre, 2002, p. 457). A related argument justifies care workers' lower pay on the grounds that "care has its own reward", i.e. "care-prone" workers accept lower wages because they "like" doing their work and derive intrinsic fulfilment from it (for a critique, see Folbre and Nelson, 2000). Other explanations have focused on the particular characteristics of care services, whose productivity might lag behind that of other industries. Mounting competitive pressures might thus translate into lagging relative wages, falling care standards (particularly in the public sector) and/or higher relative costs of care services (Himmelweit, 2007; Folbre, 2006b). ${ }^{4}$ Yet other explanations have focused on specific labour market contexts and the characteristics of care workers' employment. For example, the growing supply of migrant care workers (mostly women) might keep care-service wages relatively low (Pérez Orozco, 2009). In labour markets with wide earnings inequality and/or high unemployment, care workers might be placed at the bottom of the pay hierarchy, "crowding" these sectors and putting downward pressure on wages (Folbre, 2006b).

${ }^{3}$ On care workers' pay, see the article by Michelle Budig and Joya Misra ("How care-work employment shapes earnings in cross-national perspective") in this special issue of the International Labour Review; on working conditions, see Folbre (2006b).

${ }^{4}$ It should be noted that the "cost disease" argument (lagging productivity of care services) is strictly valid only in conditions of full employment. Before full employment, there is indeed room for care services to expand without pressure on care workers' wages, since the productivity of these services does not necessarily lag behind. 
This article analyses the relative wages and working conditions of care workers in Argentina. It argues that beyond similarities in the work content of care occupations, two - possibly mutually reinforcing - dimensions intersect to explain differences in care workers' labour market position. The first relates to labour regulations and their enforcement (i.e. whether workers are effectively protected by labour law), which shape the employment of care workers (and workers in other occupations). The second dimension stems from the ways in which the provision of care services is organized in Argentina. Given the multiplicity of care providers, prices (including free provision in some segments) and quality levels of different services, this article also argues that the working conditions and relative pay of care workers in Argentina are crucially dependent on the degree of public-sector engagement in particular services, on the "rules of the game" for other care-service providers, and on the locus of care provision (institutions or households).

In order to contextualize this analysis, the first of the remaining sections of this article reviews the provision of care services in Argentina, focusing on the health and education sectors. The second investigates the working conditions and pay of care workers in the particular context of the Argentine labour market. The third section offers an in-depth comparison of two selected care occupations, namely, early-education teaching and domestic work. A final section concludes.

\section{The provision of care services in Argentina}

In Argentina, the State plays a major role in both regulating and providing care services (usually at no cost to users) at the national, provincial and municipal levels. It is therefore a major employer in the health sector, and the main employer in education. ${ }^{5}$

The health sector in Argentina is stratified into three tiers: public-sector provision coexists with the "social security sector" (administered by unions and therefore directed to unionized, formal wage workers) and the private sector, whose services are restricted to users with relatively high incomes. In this system, the public sector has long been understood to cover the poorest segments of the population, particularly those with no access to formal employment (Anlló and Cetrángolo, 2007). During the 1980s, public hospitals, the main public-sector health institution, became increasingly short of financial resources as the public sector experienced fiscal constraints. Decentralization - a heritage of the dictatorship - exacerbated existing local and regional disparities. In this context, the market-friendly reforms of the 1990s brought deregulation of the social security sector (after which workers could choose between different union-based health services) and a wave of management reforms in public hospitals. The latter put downward pressure on costs and emphasized revenue generation, authorizing service fees to be charged to those

\footnotetext{
${ }^{5}$ This section relies heavily on Faur (2008).
} 
who could pay. These trends, which continued into the following decade, have had a profound impact on the working conditions and wages of health workers. Indeed, jobs became more precarious and "flexible", incomes more variable, and the health-sector labour force increasingly professionalized and feminized (Pautassi, 2006).

Education, by contrast, is provided free of charge in state-run institutions, which employ over three-quarters of all teachers and professors. Private schools do exist, but most are heavily subsidized by the State, which typically pays for teachers' salaries, while other costs are covered by fees. Primary education is a constitutional right and therefore nearly universal. And in 2006, the National Education Act (Law 26.206, of 28 December 2006) extended mandatory schooling up to the completion of secondary education.

During the 1990s, when early, primary and secondary education services were decentralized, long-standing disparities in service quality worsened in the absence of a concomitant resource transfer from the national administration. Indeed, responsibility for infrastructure development, management and administration, and teachers' pay was transferred to the provincial level, putting extra pressure on the budgets of poorer jurisdictions. The reform implied a profound change in the educational paradigm, leaving behind previous aspirations of equality. It triggered acute fragmentation along socio-economic lines as well as a breakdown of coordination between educational levels at a time when other social inequalities - most notably income inequality - were also worsening. In this context, teachers' working conditions and pay deteriorated in parallel with widening inequalities in the quality of the schools accessible to children from different socio-economic backgrounds (Dirié and Oiberman, 2001).

In sum, the market-friendly reforms of the 1990s diminished publicsector coverage and increased disparities in service quality, leaving it up to families to find "private" solutions to fill the resulting gaps in public provision. While gaps were indeed filled, the solutions have often reproduced existing income and gender inequalities. Poor households' access to health and education services depends on the capacity of the local government administration to provide care services (inversely proportional to the size of the vulnerable population in the jurisdiction) and their own ability to compensate for the lack of services by resorting to the unpaid care work of family members, particularly women (Esquivel, 2010). The "market solutions" available to middle- and upper-class households, by contrast, include an array of privatized health and education services, as well as the hiring of domestic workers. Although not all domestic workers perform care work themselves or work for households with dependants, they clearly ease the burden of unpaid housework, thus helping make room for the provision of care by non-dependent household members, or making it possible for women in these households to "reconcile" paid employment and unpaid care work. ${ }^{6}$

${ }^{6}$ Significant in itself is the fact that "conciliation" is naturalized as a (middle-class) women's issue: men "do" paid work, but typically do not have to "reconcile" spheres (Faur, 2006). 


\section{Care workers in the Argentine labour market}

Argentina's labour market is highly segmented along gender and income lines (Cortés, 2000). Women's labour force participation and average monthly earnings are lower, and their unemployment rate is higher, even though their average educational credentials are slightly higher than men's (table 1). Women in the lowest household income quintile participate less in the labour force than the female average - a historical trend that was reinforced by the improvement of men's employment prospects during the period of rapid economic recovery (2003-07). At the same time, the unemployment rate of women in the bottom quintile is 10 percentage points higher than the female average. Women in the highest income quintile, by contrast, show the highest rates of labour force participation and have better employment prospects, which translate into unemployment rates 10 percentage points below the female average (Cortés, 2009).

The proportion of wage workers is greater among women than men, reaching almost 80 per cent. In what represents the main feature of the Argentine labour market, however, fully half of female wage workers (and 40 per cent of male wage workers) are in unregistered or "informal" employment (Beccaria, Esquivel and Maurizio, 2005). ${ }^{7}$

Argentina's labour market is also segregated by sex: women are overrepresented in the least skilled occupations and in social and communal services (including public employment programmes), but they remain under-represented in manufacturing, construction and trade. Women are also over-represented in the public sector, which has traditionally offered registered, stable but low-paid jobs (table 1). Quantitative and qualitative evidence suggests that women require better educational credentials than men (all other things being equal) to access protected jobs (Esquivel, 2007). Moreover, they generally suffer from both subtle and overt discriminatory practices (Novick, Rojo and Castillo, 2008).

This article's focus on the broadly defined category of care workers allows a new reading of these findings, which reflect long-standing features of the Argentine labour market. It can also shed light on the processes that might underpin them. Yet it must be remembered that the averages presented in table 2 result from markedly different situations on account of the widely divergent types of care occupations held by women.

No less than one-third of all employed women in Argentina are wage workers in care occupations. ${ }^{8}$ Roughly half of them are teachers, professors, doctors, nurses and related aides - occupations that require relatively high educational credentials and skills (see figure 1). That these occupations are

${ }^{7}$ Workers are considered as "unregistered" when employers do not pay their social security contributions. In such cases, workers are often also deprived of unemployment insurance, health care, annual bonuses, family allowances, etc.

${ }^{8}$ Care occupations, as defined above on the basis of England, Budig and Folbre (2002), do not include managerial or administrative positions. 
Women, gender and work

Table 1. Labour market indicators by sex (percentages of urban total in the second quarter of 2006)

\begin{tabular}{lcc}
\hline & Women & Men \\
\hline Labour force participation rate & 38.8 & 55.3 \\
Employment rate & 33.7 & 50.7 \\
Unemployment rate & 13.0 & 8.4 \\
\hline Employer & 2.3 & 5.4 \\
Own-account workers & 16.0 & 21.7 \\
Public-sector wage workers & 18.2 & 12.1 \\
Registered private-sector wage workers & 23.1 & 32.3 \\
Unregistered private-sector wage workers & 16.1 & 26.3 \\
Domestic workers & 17.0 & 0.2 \\
Employment programmes & 5.6 & 1.3 \\
Family workers & 1.8 & 0.7 \\
Total & 100 & 100 \\
Rate of wage employment & 79.9 & 72.2 \\
\hline Registered wage workers (percentage of total wage employment) & 50.8 & 59.9 \\
\hline Average years of schooling & 11.4 & 10.5 \\
Average hours worked & 26 & 38 \\
Monthly earnings (AR $\$, 2006)$ & 709 & 1,066 \\
Hourly wage (AR $\$$, 2006) & 5.65 & 5.95 \\
Note: In 2006, AR $\$ 100$ was worth approximately US\$32. & & \\
Source: Author's calculations based on the "Permanent Household Survey" (EPH) of the National Institute of \\
Statistics and Censuses. & & \\
\hline
\end{tabular}

typically performed in state-run health and educational institutions might partly explain the slight over-representation of women in the public sector. The other half of female care workers are in domestic service. They have low educational credentials and are usually "unskilled", performing their jobs in the secluded sphere of the employer's home. Virtually all domestic workers are unregistered, accounting for almost 40 per cent of all unregistered female wage workers (see below). Indeed, unregistered female wage employment cannot be understood without analysing domestic work.

In contrast, care occupations account for just over 3 per cent of all male employment, and 5 per cent of male wage employment. Men in care occupations are mainly teachers, professors and doctors. It is therefore not surprising that over 80 per cent of these men have complete or partial tertiary education; 29 per cent perform professional work and 56 per cent are engaged in technically skilled work. The major role of public employment in the areas of education and health care accounts for the fact that half of the male care workers perform their jobs in state-run institutions, with above-average levels of employment protection. These factors all contribute to men's average hourly wages being 50 per cent higher than those of women in care occupations (table 2). 
Figure 1. Care workers in Argentina
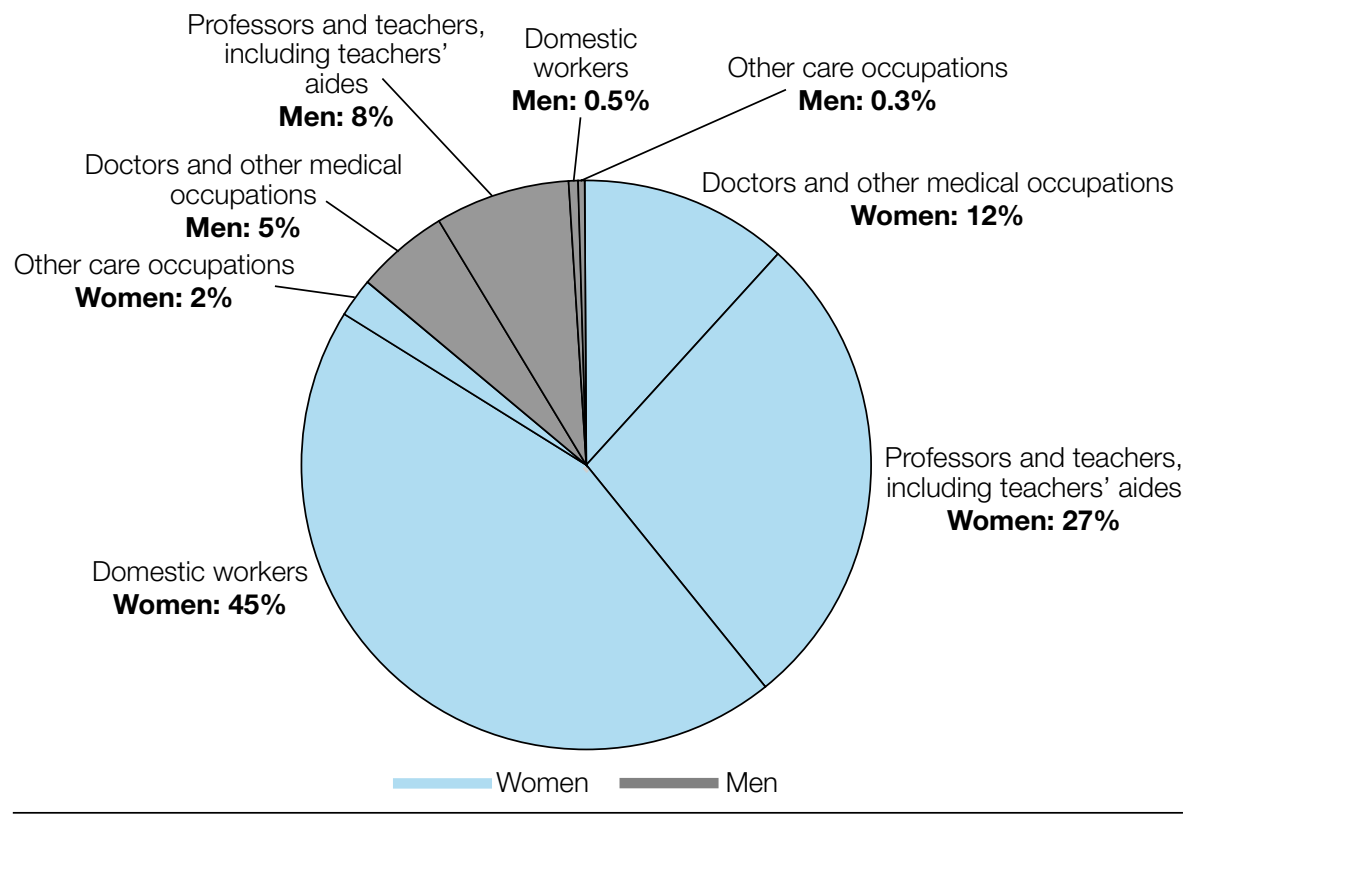

The tiny proportion of male care workers indicates that care occupations are highly feminized: on average, 86 per cent of all care workers are women. The proportions are practically 100 per cent among domestic workers, 77 per cent among teachers and professors, and 69 per cent among doctors, nurses and nursing aides. In Argentina, care occupations are female occupations - a fact that could in itself influence care workers' working conditions and relative pay. However, previous findings suggest that a high proportion of women in any (broadly defined) occupation does not per se produce downward pressure on hourly earnings, as sex segregation theory would predict (Esquivel, 2007).

Care workers in Argentina are therefore a heterogeneous group - in terms of educational levels, registration, type of employer, type of care occupation and degree of feminization. It is possible, however, that even when these differences are statistically controlled for, care workers may constitute a distinct pool of workers, equally penalized by the care content of their occupations, as England, Budig and Folbre (2002) suggest for the United States. In order to test this hypothesis in Argentina, a series of Ordinary Least Squares (OLS) regressions on the natural logarithm of hourly wages were performed for female and for male wage workers. A care occupation dummy variable was included in some of the regressions, while other regressions disaggregated occupations into broad groups - doctors and other medical occupations; professors and teachers, including teachers' aides; domestic workers; other care occupations, 
Women, gender and work

Table 2. Selected characteristics of care workers by sex (percentages of urban total in the second quarter of 2006)

\begin{tabular}{lcc}
\hline & Women & Men \\
\hline Registered & 43 & 70 \\
Working in a state-run institution & 27 & 56 \\
\hline Partial or no primary schooling & 8 & 1 \\
Completed primary school & 23 & 4 \\
Incomplete secondary schooling & 14 & 4 \\
Completed secondary school & 13 & 10 \\
Partial or complete tertiary education & 42 & 81 \\
\hline Professional & 6 & 29 \\
Technical & 34 & 56 \\
Semi-skilled & 7 & 11 \\
Unskilled & 53 & 4 \\
\hline Monthly earnings (AR \$, 2006) & 554 & 1,057 \\
Hourly wage (AR $\$, 2006)$ & 6 & 9 \\
Hours per week & 26 & 32
\end{tabular}

Source: Author's calculations based on the "Permanent Household Survey" (EPH) of the National Institute of Statistics and Censuses.

including therapists, nannies, etc. (table 3). Although this exercise could arguably be seen as a highly artificial construct - not exempt of technicalities ${ }^{9}$ - it is valuable because it might indicate some avenues for change.

The results indicate that women working in care occupations are not necessarily penalized as a group - the care occupation dummy gets a positive sign but is not statistically significant when included in the regression, yet its value becomes negative ( -6 per cent) and significant after controlling for sex composition (FEM) of occupations. In the case of men, the care occupation dummy is statistically significant (though weakly) and negative ( -5 per cent) irrespective of the chosen specification. However, these are the results of highly heterogeneous situations. When care occupations are disaggregated, a wage penalty of approximately -10 per cent among doctors and other medical occupations emerges as remarkably robust for both women and men. This result is consistent with the deterioration of working conditions in health-care occupations in the past 15 years. Wage differentials in other care occupations are not statistically significant, and are therefore explained by factors other than the care

${ }^{9}$ As some groups of care workers are highly homogeneous (most domestic workers, for example, are unregistered, have low education, and work for households in a highly feminized occupation), issues of colinearity may arise when controlling for these various characteristics. OLS regressions were performed checking for variance inflation factors (VIFs). All values are reasonable (always $<10$ and mostly $<5$ ), pointing to the validity of chosen variables and of the regressions as a whole (table 3$)$. 
Care workers in Argentina
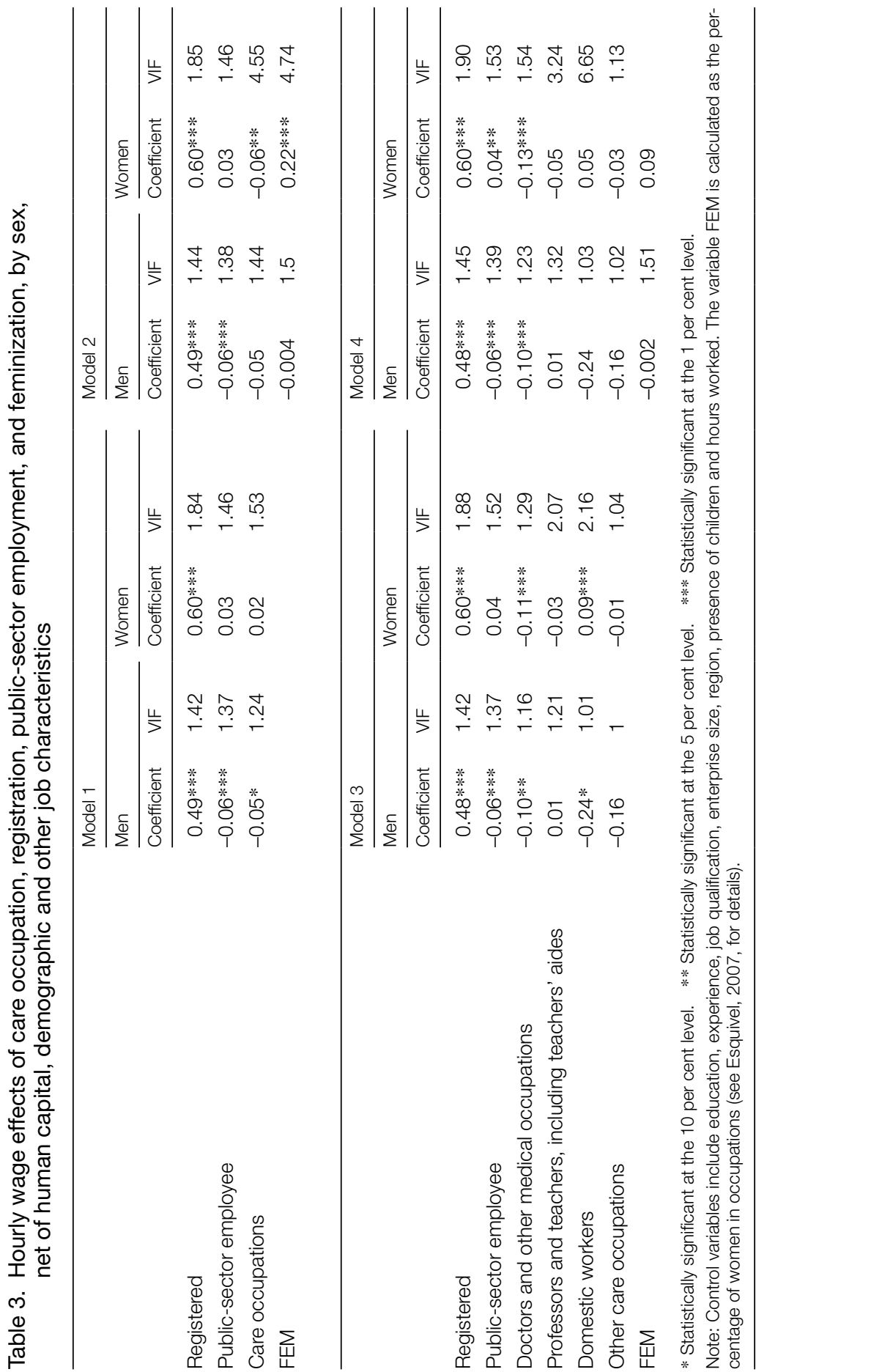

(1) 
content of the work they involve. ${ }^{10}$ Indeed, after controlling for human capital, demographic characteristics and other job characteristics, the main determinant of hourly wages is the level of employment registration (table 3 ). Thus, registered female wage workers earn 60 per cent more than their unregistered counterparts. Among men, the registration premium is 49 per cent. While men are penalized if they work for the public sector ( -6 per cent), women get a premium of +4 per cent if they do (Model 4 in table 3 ).

These results show that aside from medical occupations, working conditions and pay in care occupations cannot be separated from the overall labour market features identified above. In Argentina, improving care workers' relative wages will thus require substantial progress in registration levels - as is the case with other wage workers. The results also point to the relative wage advantage of female workers in the public sector (vis-à-vis other women in wage employment), which might explain their above-average employment levels in public institutions. Importantly, these results do not indicate that domestic workers are penalized per se, maybe because their low qualifications ( -50 per cent) and lack of registration ( -60 per cent) fully account for their disadvantages.

\section{A comparison of two "polar" care occupations: Early-education teaching and domestic service}

The finding that care workers' wages depend on the regulation and overall structure of the labour market - along with the aggregate nature of the statistical exercise performed in the previous section - called for in-depth analysis of two care occupations: earlyeducation teachers and domestic workers. ${ }^{11}$ These care occupations are both related to the provision of care for a particular group of dependants (children). Their work contents therefore overlap. At the same time, these occupations are sufficiently different ("polar") in terms of their employment characteristics - regulatory framework and actual labour protection, working conditions - which are themselves dependent on general conditions in the care sector and the "locus" of care provision. Clearly, this in-depth analysis does not "correct" for human capital, demographic and other job characteristics, as the previous one did. ${ }^{12}$ Rather, it characterizes the selected occupations in order to find elements that could help enhance the position of care workers.

${ }^{10}$ Domestic work gets a positive and significant value in specifications not controlling for sex composition.

${ }^{11}$ The study of female domestic workers is based on Cortés (2009), who processed data from the "Permanent Household Survey" (EPH). The study of female early-education teachers is based on Cerrutti (2008), who processed data from the 2004 National Census of Teachers (Ministry of Education, Science and Technology).

12 I will therefore not analyse relative earnings, which are heavily influenced by these characteristics. A comparison of means shows that female primary teachers' monthly income was AR $\$ 826$, and hourly wages AR $\$ 9.4$, in the second quarter of 2006 (these figures are the best available proxy for female early-education teachers' earnings). The corresponding figures for domestic workers were AR \$304 and AR \$3.3. 


\section{Demographic and job-related characteristics}

Both early-education teaching and domestic work are highly feminized occupations, deeply charged with particular gender meanings (see below). This, however, is where the similarities end, for the women working in these two occupations come from different social backgrounds, have very different work experiences and employment prospects, and present enormous differences in terms of educational attainment.

Early-education teaching is a highly professionalized and regulated occupation. Work as an early-education teacher requires a tertiary-level degree: 97 per cent of all early-education teachers hold one. ${ }^{13}$ Teaching takes place in crèches for children under the age of three and in kindergartens for children aged between three and five years, which are run and/or regulated by the State.

The daily organization of the teachers' work is clearly defined on the basis of the number of hours pupils attend the institution, the size of the classes, parents' and teachers' responsibilities, etc. Furthermore, particularly in the public sector, early-education teaching is organized as a "closed internal labour market" in which entry is possible only at the base of the pyramid and opportunities for development and promotion are associated with seniority and, to a lesser extent, continuous training.

Female early-education teachers ${ }^{14}$ - i.e. 95 per cent of all early-education teachers and 99 per cent of classroom teachers - are younger than the average age of employed women, as might be expected given that early education has been expanding (Faur, 2008). Their below-average age might also be related to the fact that teacher training takes three years - making it possible to graduate and start teaching at the age of 21 . Female early-education teachers are also more educated and better paid, on an hourly basis, than are female wage workers overall; as a group, they also receive higher monthly wages than the average for female care workers.

At the other extreme, domestic work is a care occupation without "barriers to entry" - one of the few employment options open to women from poor households, who alternate between domestic work, public employment programmes, unregistered work in trade, and unemployment. Indeed, 30 per cent of the employed women in households with incomes in the first quintile are domestic workers, while the proportion is close to zero in households in the fifth quintile. The demand for domestic services is also highly responsive to changes in middle- and upper-class incomes: it contracted sharply in the immediate aftermath of the 2002 macroeconomic crisis and recovered only in 2006, when public employment programmes started to shrink (Cortés, 2009).

Although many female domestic workers are young, a substantial number of them are middle-aged, being mostly heads of households (35 per cent)

${ }^{13}$ These tertiary-level degrees are awarded by specialized institutions, usually after shorter courses than those required for university degrees.

${ }^{14}$ Eleven per cent of early-education teachers are directors or hold administrative positions, 76 per cent are classroom teachers, and 13 per cent are teachers' aides. 
or spouses (39 per cent). A high proportion of domestic workers are internal migrants (37 per cent) or migrants from bordering countries and Peru (20 per cent). Domestic workers' levels of educational attainment are the lowest among female workers (although the increasing proportion of migrants from neighbouring countries, with higher educational levels, is raising the average educational level); 16 per cent of female domestic workers have not completed primary school, and 61 per cent have not completed secondary school. Their average monthly earnings are not only lower than those of female wage workers overall, but also lower than the statutory "minimum wage".

\section{Regulatory framework and actual labour protection}

Labour regulation is a key factor in explaining the different levels of registration of the workers in the two occupations examined here.

Early-education teachers in public establishments have rights and obligations defined by the "Teachers' Statute"15 depending on whether they are in a tenured position (permanent teachers) or not (interim and substitute teachers). Permanent teachers enjoy the fullest range of workers' rights, including employment security. The rights of interim and substitute teachers are more limited: though registered, they are not tenured, ${ }^{16}$ and therefore not fully covered by the provisions of the Teachers' Statute. Teachers in private establishments are subject to the Employment Contracts Act, ${ }^{17}$ which gives them the same rights and obligations as other registered wage workers but less than those granted by the Teachers' Statute. ${ }^{18}$ Virtually all early-education teachers are registered workers.

As is the case at other educational levels, early-education teachers in the public sector (in contrast to the private sector) are highly unionized. Teachers' unions take part in collective bargaining, on a centralized basis, with educational authorities. ${ }^{19}$

While the Teachers' Statute provides teachers in early-education establishments with rights beyond those set forth in the Employment Contracts Act, the latter explicitly excludes domestic workers. Domestic work is regulated by the 1956 Domestic Service Regulations (made under Legislative Decree $326 / 56$ ), which covers employees working for a period of one month or more, at least four hours per day and no less than four days per week for the same employer. Workers below this threshold are not considered wage workers but

${ }^{15}$ Act No. 14473, of 12 September 1958, to approve the Statute governing the teaching staff of the Ministry of Education and Justice (in Boletín Oficial, 27 November 1958).

${ }^{16}$ In the public sector, the right to be considered for tenure is neither automatic nor decided by the educational institution, but depends on political decisions.

${ }^{17}$ Act No. 20744, of 11 September 1974, to approve the rules governing contracts of employment (in Boletín Oficial, 27 September 1974, No. 23003, p. 2). For an English translation, see Legislative Series, 1974 - Arg. 2, Geneva, ILO.

${ }^{18}$ Remuneration is an exception to this rule, since the wages in public establishments set minimum wages in privately run schools.

${ }^{19}$ Early-education teachers' wages are negotiated along with primary school teachers' wages. 
own-account workers, and their employers are not required to register them. ${ }^{20}$ The labour rights granted to domestic workers within this legal framework are not on a par with those enjoyed by other wage workers. At best, their rights partially replicate those granted to formal wage workers, as in the case of severance pay, sick leave, and annual vacations. However, domestic workers are completely deprived of some important rights, including the right to state-funded maternity leave and entitlement to family allowances. ${ }^{21}$ This makes them particularly vulnerable when they become pregnant or have children (ELA, 2009).

Beyond the weakness of this legal framework, domestic work has traditionally been (and continues to be) characterized by high levels of unregistered employment. In the second half of 2006, only 8.6 per cent of female domestic workers were registered - i.e. their employers paid their social security contributions - and another 2.2 per cent contributed as own-account workers. These figures, however, do not reflect the positive impact of the registration initiative on domestic work that started in early 2006. This initiative involved deducting domestic workers' wages and social security payments from employers' income tax, together with simplified procedures for registration and payment of contributions, and an intense advertising campaign. According to administrative registries, as much as one-third of domestic workers were registered by the end of 2008 - a huge improvement from the situation in 2006 (Estévez and Esper, 2009). ${ }^{22}$

Unlike in business, the employment relationship in domestic service is between an employee and a household. This highly personalized context explains the weak bargaining position of domestic workers, which is compounded by extremely low levels of registration, the absence of unionization and collective bargaining, and high turnover rates, as unregistered domestic workers can be fired without notice or severance pay (Cortés, 2009).

\section{Working conditions}

Working conditions (including tasks, schedules, workloads and job stability) are also associated with the characteristics of the employment relationship, the care sector, and the locus or "site" of care provision. While most early-education teachers work in public (66 per cent) or private establishments subject to supervision by educational authorities, female domestic workers are employed by households. In other words, employers' visibility and the degree to which they comply (or can be compelled to comply) with labour regulations differ widely.

${ }^{20}$ This differentiation has in fact contributed to discourage registration - it could be very difficult to prove whether a domestic worker was above or below this threshold in court.

${ }^{21}$ Registered female wage workers have the right to three months of maternity leave. Family allowances are regular or lump-sum subsidies to help workers cover the costs associated with childbirth and adoption, children and children's schooling, marriage, etc.

${ }^{22}$ Although this improvement may imply some cost to the state budget, the tax allowance has an upper limit, roughly equivalent to six to nine monthly minimum wages, which means that registered domestic workers are only partly subsidized by the State. In the short term, however, registration increases tax collection when compared with non registration. 
The high proportion of tenured teachers (78 per cent) and their consequent job stability are reflected in the average seniority of this group: 55 per cent of early-education teachers have at least ten years of seniority, with the proportion rising to 87 per cent for principals and assistant principals. These percentages are even higher in state-run establishments -72 per cent of teachers and 89 per cent of principals and assistant principals - translating into greater job stability (less turnover) and better career opportunities for teachers in the public system. Seniority in teaching is associated not only with opportunities for promotion, but also with higher pay. ${ }^{23}$

In terms of teaching hours, 61 per cent of early-education teachers have workloads of 13 to 24 "classroom hours" (i.e. 45-minute periods) per week approximately equivalent to a half-time workload. By contrast, 40 per cent of domestic workers work up to 15 hours weekly (i.e. under the threshold for coverage by Legislative Decree 326/56), 33 per cent of them work between 16 and 34 hours, and 27 per cent of them work 36 hours or more. Half of the latter group work 45 hours or more (i.e. they are "over-employed"). Such heavy workloads are not exclusively associated with live-in arrangements, as only 4 per cent of domestic workers live in their employer's home.

Over one-third (36 per cent) of domestic workers have been in their jobs for no more than a year, while 26 per cent of them have been engaged between one and five years. A great majority of female domestic workers (78 per cent) work in a single home (i.e. they have only one employer), while 13 per cent of them work in two homes. Thus, the opportunity to increase hours of work (and monthly income) is associated more with the needs of a single employer than with the possibility of working for multiple employers. Indeed, 36 per cent of domestic workers seek to work more hours and are thus underemployed; and 23 per cent of them hold additional jobs, even when domestic work is reported as their "primary occupation". This shows the severe limitations of earnings derived from domestic work.

\section{Gender images}

The foregoing examination of early-education teaching and domestic work does not explain the fact that both occupations are almost completely feminized. Questioning the complex and evolving meanings that these occupations hold for the workers who perform them - and for society at large - might help to explain this.

As a working hypothesis, it could be argued that the work contents of both occupations are perceived as extensions of two romanticized ideals: that of the "good mother" in the case of early-education teachers, and that of the "good wife" for domestic workers. Neither of these "ideals" is innocent, as they both symbolically deprive these women of their labour status - i.e. their care occupation is not considered a "proper" job. As Fischman puts it regarding the

${ }^{23}$ Early-education teachers with ten years of seniority earn 50 per cent more than their junior colleagues, while those with 20 years of seniority earn 100 per cent more. 
teaching profession, "the lack of recognition of the specific characteristics of women who work at schools [...] and their replacement by romanticized ways of naming them associated to domesticity supports 'domestication' and childlike social treatment of teachers" $(2005$, p. 8). As for domestic work, these social meanings are highlighted in the definition of its content simply as comprising the tasks that are "part of domestic life" (Legislative Decree 326/56) and, therefore, women's work.

The gendered meanings of early-education teaching are forcefully contested by teachers themselves, and might conflict with families' demands. As explained by former pre-school director Patricia Redondo, early-education teachers "are not grandmothers, [they] do not 'hold' babies; [crèches and kindergartens] are public institutions.'24 Early-education teachers rightly claim recognition of their role as educators - as opposed to "mere" carers - on the basis of their professionalization (as opposed to "natural" knowledge) and institutionalization, i.e. work in the public sphere as distinct from the household and family.

In a characterization of the views that households hold on domestic workers, the National Tax Collection Office (AFIP) found that "homeowners" view themselves as "providers of work opportunities", emphasizing the refuge role of this occupation in times of crisis. ${ }^{25}$ Moreover, "employers do not feel responsible for the short-term (health) and long-term (retirement) needs of domestic workers. This is partly due to the fact that this relationship takes place in the domestic sphere,"26 which is difficult to reach and control by public authorities. Some of these ideas were challenged in the advertising campaign that AFIP launched in support of its registration initiative, emphasizing employers' "responsibilities" towards domestic workers, even though other gender images were not questioned (e.g. the employer is always another woman, as if housework were only a woman's issue). However, the campaign helped to recast domestic work as a formal employment relationship.

\section{Conclusions}

Based on a broad definition of care work derived from England, Budig and Folbre (2002), this article has shown that care workers in Argentina are not a homogenous group, even though most of them are women and their occupations display some similarity in terms of job content. Differences in their socioeconomic characteristics and skills, as well as the types of care work they engage in, all contribute to this heterogeneity. However, two factors have

\footnotetext{
${ }^{24}$ See María Rosa Mayer's interview of Patricia Redondo: "Nosotros no recibimos bebés, no somos abuelas, somos instituciones públicas", in Redacción y Editorial - Entrevistas, No. 86 (1 Aug. 2008), at: http://redaccionyeditorial-entrevistas.blogspot.com/2008/08/educacin-patriciaredondo.html [accessed 12 Oct. 2010].

${ }^{25}$ This view also permeates the language of Legislative Decree 326/56, which reflects a patriarchal model of the family and the strong prerogatives of male "homeowners".

${ }^{26}$ Verbatim responses of an AFIP official quoted by Estévez and Esper (2009, p. 19).
} 
proved crucial in explaining the working conditions and pay of care workers: the particular ways in which the provision of care services is organized, and the degree of employment protection care workers enjoy.

The analysis suggests some avenues for enhancing the position of care workers in Argentina. The case of early-education teachers demonstrates that even in a care occupation clearly identified with motherhood, working conditions and pay can improve with professionalization and registration, the latter being guaranteed by both public-sector provision and a strong legal framework. Conversely, occupations related to health care might have experienced downward pressure on wages as a result of the expansion and deregulation of the market for health-care services.

The scale of female domestic employment as well as wages and working conditions in this occupation are directly related to the wide income inequalities in Argentine society, and to the fact that domestic workers are at the bottom of the pay hierarchy. Improving their relative pay through "indicative wages", as it is currently done, might improve their position. Yet, efforts to promote the registration of domestic workers should be continued, along with improvements in the legal framework that regulates their occupation. Indeed, the situation of domestic workers will not improve until they are treated on a par with other registered wage workers.

\section{Post scriptum}

On 8 March 2010, the Executive submitted to the National Congress a new legal framework for domestic workers, which has yet to be considered by the country's lawmakers. If passed without amendment, it will equalize most of domestic workers' rights with those of other wage workers.

\section{References}

Anlló, Guillermo; Cetrángolo, Oscar. 2007. "Políticas sociales en Argentina: Viejos problemas, nuevos desafíos", in Bernardo Kosacoff (ed.): Crisis, recuperación y nuevos dilemas. La economía argentina 2002-2007. Santiago de Chile, ECLAC, pp. 395-426.

Beccaria, Luis; Esquivel, Valeria; Maurizio, Roxana. 2005. "Empleo, salarios y equidad durante la recuperación reciente en la Argentina”, in Desarrollo Económico - Revista de Ciencias Sociales, Vol. 45, No. 178, pp. 235-262.

Cerrutti, Marcela. 2008. La situación social y laboral de las docentes de nivel inicial en la Argentina. Geneva, UNRISD.

Cortés, Rosalía. 2009. Labour regulations' ambiguity and quality of working life: Domestic servants in Argentina. Paper presented to the ILO Conference on Regulating Decent Work, Geneva, 8-10 July. Geneva, ILO.

-. 2000. "Argentina: La calidad del empleo femenino urbano en los noventa", in María Elena Valenzuela and Gerhard Reinecke (eds): ¿Más y mejores empleos para las mujeres? La experiencia de los países del Mercosur y Chile. Santiago, ILO, pp. 103-133.

Dirié, Cristina; Oiberman, Irene. 2001. "La profesión docente en el mercado de trabajo actual", in Estudios del Trabajo, No. 22, pp. 61-92.

ELA (Equipo Latinoamericano de Justicia y Género). 2009. Informe sobre género y derechos humanos. Vigencia y respeto de los derechos humanos de las mujeres (2005-2008). Buenos Aires, Biblos.

England, Paula; Budig, Michelle; Folbre, Nancy. 2002. "Wages of virtue: The relative pay of care work", in Social Problems, Vol. 49, No. 4, pp. 455-473. 
Esquivel, Valeria. 2010. "Unpaid care work in the city of Buenos Aires", in Debbie Budlender (ed.): Time use studies and unpaid care work. New York, NY, UNRISD/Routledge, pp. 197-222.

-. 2007. "Género y diferenciales de salarios en Argentina", in Marta Novick and Héctor Palomino (eds): Estructura productiva y empleo: Un enfoque transversal. Buenos Aires, Ministerio de Trabajo, Empleo y Seguridad Social, pp. 363-392.

Estévez, Alejandro M.; Esper, Susana C. 2009. La relación entre el sistema impositivo y la desigualdad: El papel de la Administración Tributaria en la cohesión social. Observatory on Structures and Institutions of Inequality in Latin America, Working Paper Series No. 19. Coral Gables, FL, Center for Latin American Studies, University of Miami.

Faur, Eleonor. 2008. The "care diamond": Social policy regime, care policies and programmes in Argentina. Research Report 3. Geneva, UNRISD.

-. 2006. "Gender and familywork reconciliation: Labor legislation and male subjectivities in Latin America", in Luis Mora, María José Moreno Ruiz and Tania Rohrer (eds): Social cohesion, reconciliation policies and public budgeting: A gender approach. Mexico City, UNFPA/GTZ, pp. 127-149.

Fischman, Gustavo E. 2005. "Imágenes de la docencia: Neoliberalismo, formación docente y género", in Revista Electrónica de Investigación Educativa, Vol. 7, No. 2, available at: http://redie.uabc.mx/vol7no2/contenido-fischman.html [accessed 22 Sep. 2010].

Folbre, Nancy. 2006a. "Measuring care: Gender, empowerment, and the care economy", in Journal of Human Development, Vol. 7, No. 2, pp. 183-199.

-. 2006b. "Demanding quality: Worker/consumer coalitions and 'high road' strategies in the care sector", in Politics and Society, Vol. 34, No. 1, pp. 11-31.

-; Nelson, Julie. 2000. “For love or money - or both?”, in Journal of Economic Perspectives, Vol. 14, No. 4, pp. 123-140.

Himmelweit, Susan. 2007. "The prospects for caring: Economic theory and policy analysis", in Cambridge Journal of Economics, Vol. 31, No. 4, pp. 581-599.

- (ed.). 2000. Inside the household: From labour to care. Houndmills, Palgrave Macmillan.

Novick, Marta; Rojo, Sofía; Castillo, Victoria (eds). 2008. El trabajo femenino en la postconvertibilidad. Argentina 2003-2007. Documento de Proyecto. Santiago de Chile, ECLAC.

Pautassi, Laura C. 2006. "El empleo en salud en la Argentina. La sinergia entre calidad del empleo y calidad de la atención", in María Nieves Rico and Flavia Marco (eds): Mujer y empleo. La reforma de la salud y la salud de la reforma en Argentina. Buenos Aires, Siglo XXI Editores (with ECLAC, GTZ and One World), pp. 193-234.

Pérez Orozco, Amaia. 2009. Global perspectives on the social organization of care in times of crisis: Assessing the situation. Gender, Migration and Development Series, Working Paper No. 5. Santo Domingo, UNINSTRAW.

Razavi, Shahra. 2007. The political and social economy of care in a development context: Conceptual issues, research questions and policy options. Gender and Development Programme Paper No. 3. Geneva, UNRISD. 